\title{
The Learning Ecology of Generation X, Y And Z
}

\author{
Aminudin Mohamed Kassim ${ }^{1}$, Mohd Mahzan Awang ${ }^{2}$, Abdul Razaq Ahmad ${ }^{3}$ \& \\ Anuar Ahmad ${ }^{4}$ \\ ${ }^{1234}$ Faculty of Education UKM, MALAYSIA \\ E-mail: aminudin9109@gmail.com
}

\begin{abstract}
This paper aims to discuss the ecology of among the $\mathrm{X}, \mathrm{Y}$ and $\mathrm{Z}$ generations and to discuss the application of appropriate learning methods to use based on generation differences. With the change of generations, the educators are having trouble in adapting the learning styles according to the differences in their ecology. The main focus of this paper is to explain the similarities and differences in learning ecology between generation group in order to identify the suitable learning style for each generation and increase student motivation to study. The discussion in this paper based on references to relevant articles and journals by focusing on the learning ecology or environment, the learning of generation group and the effect of learning style in generation group education. The theory referred to in this paper is taken from Bronfenbrenner's theory of ecology. This theory is focused on the chronosystem layer as it is more appropriate to be linked to the learning ecology of each generation. This theory also supported by Kolb's theory of learning styles. The ecological factor results the difference in learning styles for each generation groups. For current generation, the learning ecology vary from the older generation as the influence in technology majorly resulting the difference in learning style. The results of this paper intended to help educators to adapt teaching methods for current generation.
\end{abstract}

Keywords: Learning ecology, generation X, Y and Z, learning style.

\section{Introduction}

The world nowadays is on developing period of technology, the usage of traditional teaching methods is unsuitable for use. The variety of student's backgrounds make the effectiveness of each method used by teachers not achieved extensively. Teachers always face many challenges when receiving different backgrounds to apply effective lessons in class. Teachers not bounded by the conventional teaching method to implement one of the skills needed, but they need to adapt with the ecological learning for each generation because nowadays, ecological changes in generations play an important role in receiving the skills taught. Teachers need to use the knowledge to implement skills that can be associated with a student's background in order to adapt to effective teaching. Educators in this era face more challenges due to the change in generations that aligned with the rapid technological development.

To adapt appropriate teaching methods, educators need to know the appropriate learning style used by students from the generation. Besides school, learning is also happening at home. Parents also need to know their 
children's learning ecology to support children's learning in schools and in homes. Home Learning has a better impact because learning in the family becomes a very effective stimulus to develop lifelong learning in children (National Institute of Adult Continuing Education, 2003). According to Kaplan (2001), the Inter-generation education managed to meet the development needs of the youth and adults that are appropriate to the age are the strengths and assets of each generation. According to Kaplan (2001), the Inter-generation education managed to meet the development needs of the youth and adults that are appropriate to the age are the strengths and assets of each generation. Therefore, it is important for parents and teachers to know the ecological learning for every generation $\mathrm{X}, \mathrm{Y}$ and $\mathrm{Z}$ to distinguish the appropriate methods in applying effective learning.

Current education has undergone many changes in their curriculum. There are new skills that were introduce to customize the current needs. However, the students' achievement in academic seem to be unsatisfying where Malaysia is still in a group that are behind in TIMSS and PISA. When we look at the curriculum introduced, the skills you want to apply have been better for students. However, there are some educators are still continuing the traditional method due to being less aware of the current generation needs

\section{Concept of Ecological Learning}

Ecology in learning means a learning environment that affects students' learning style. The context of this learning ecology relates to the difference in generations as they have different lifestyle, curriculum and social environment. Purkey (1970) believes that the environmental condition can affect the student's self-concept. The different environmental differences between generations make learning style for each generation also experiencing changes. This learning environment should be study to assist educators to adapt appropriate teaching methods to assist in the application of important skills in students. This generation of cohort implicates the learning process in three things, which are the difference in learning, approach to learning, and levels of student intellectual development (Felder \& Brent, 2005).

\section{Learning Styles}

As we are aware, each generation has different backgrounds especially when it comes to technological development. This in fact makes learning style for each generation vary. Worley (2015) noted that the difference in behavior, motivation and approach to how learning is an important thing to raise learning for students. By understanding the learning style that existed, teachers can plan an effective learning style in teaching the students in need (Azizi Yahaya, 2003). Frank Romanelli (2009) stated, a better knowledge and understanding of learning styles may become increasingly critical as classroom sizes increase and as technological advances continue to mold the types of students entering higher education. It is important for us to study the learning style of generation group to implement a proper teaching method for the students.

\section{Bronfenbrenner Ecological Theory}

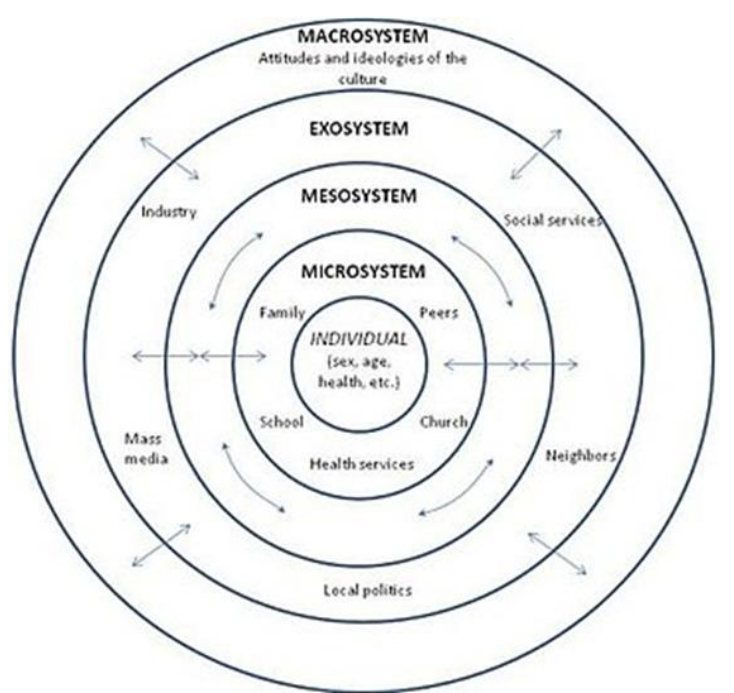

Figure 1: Bronfrenbrenner's Ecologycal System

In Bronfenbrenner's theory of ecological system, there are five important features in individual development i.e. microsystems, mesosystems, exosystems, macrosystems and chronosystems. The system taken in this study is the most external layer of the system. According to Bronfenbrenner (1984), chronosystem means changes that occur to the conduct and behavior as well as the children's culture within a period. In this theory, the chronosystem seems to be more associated with the difference in attitudes and behavior in each generation. Even in this theory stated that the chronosystem is the outer layer, it is nowadays is the major factor that affect generations behavior. The environmental changes that occur in fact majorly affect the community in developing skills, experience and behaviors. From technology perspective, generations in this era are advanced and more distant as the pace of technology now has a profound impact on students' learning style. If in early days many students refer to teachers and books, students are now more using the internet as a major reference source.

Learning style for many individuals are influence by the environmental factor, which is the ecology of each individual. The Kolb's theory of Learning Style (1984) stated 
that learning is a holistic process. In this theory, the learning process can clearly show the ways of how knowledge is obtaining through the interaction of one with its surroundings. The environment differences experienced by each generation will certainly affect the ecological learning of the generation.

\section{The Concept Of X, Y And Z Generation}

There are three generations that currently involved in education system. Generation $\mathrm{X}$ refers to the groups that were born between 1960 and 1970. This generation is born immediately after baby boom, which are the generation born after the third World War. This generation of $\mathrm{X}$ has stepped into the work environment if viewed at present time. According to Seacrest (1996), the X-generation refers to a group of individuals born between 1961 and 1983. They are generation that were growing in economic restructuring and globalization. Generation $\mathrm{X}$ is often associated with strict and highly dependent environment. According to Cambiano, De Vore and Harvey (2001), in order to maintain a prime learning environment for generation $\mathrm{X}$, instructor need to maintain a very structured environment. It is because they need carefully laid out plans of what expected of them in learning situation including knowing assignments that are due in the future, the parameter of each lesson and the sequential steps involved in all assignments.

Generation Y is a group born between 1980 and the early 1990. This generation is a generation that grow up with the development of technology such as television appearances, video games and mobile phones and the Internet. This generation prefers to pursue something self and more confident, multitasking, and optimistic (Hira, 2007). They are the first generation to use email, short messaging system and mobile phone since childhood and teenagers (Tyler, 2007). This part of Y's generation has already begun a step into career.

Generation Z refers to generations born in 1995 until 2010. This generation is mostly in the education system of schools and higher education. Generation $\mathrm{Z}$ has undergone global recession, global warming issues, awakening of mobile devices, and cloud computing (cloud). Seemiller and Grace (2016) found this generation driven by various motivation, learning style, characteristics, skills, and social concerns from the past generation. Looking at this generation learning ecology, Darla Rothman (2014) in his study says the generation of $\mathrm{Z}$ prefers to see a colored image and only read less than $20 \%$ of the text. Forty three percent of teenagers in generation $\mathrm{Z}$ wanting to learn to use the Internet, $38 \%$ is more likely towards a mixed method while $16 \%$ is more likely to use books for learning. In such study, it clearly shows that media and gadgets in learning process are mostly in need but teachers have to be smart to apply the technology in teaching process.

The three generations have undergone a different life environment as the development of technologies vary for each generation. It is undeniable that the environmental factors affect the learning style for one generation. Therefore, educators need to have different approaches to implement the necessary skills in the generation.

\section{Discussion}

The difference in a generation of $\mathrm{X}, \mathrm{Y}$ and $\mathrm{Z}$ lifestyle is one thing that is commonly known. Teachers need to ensure that the teaching methods used are according to the ecological learning for each generation. According to Carbo \& Hodges (1988), the way of learning style a trainee with training methods can enhance the ability and ability of the trainees to concentrate and learn. Feller (1996) said that when no adaptation or compatibility exists between the learning style and the method used by the trainer, the trainees will quickly be bored and refuse to focus, making activities with halfhearted. Therefore, teaching using only paper will make them bored and lack of focus.

Teachers need to use interesting teaching methods so that students will focus in the class. Gordon (1974) believes that teachers can keluarga students from behaviors that are opposed to the rules easily through the modification of classroom environments. This involves planning and arranging classrooms to suit the students' needs. If we refer to the generation $\mathrm{Z}$ sociology, they are more depended on digital technology, the use of virtual device tools can help attract students to learn.

Generation of $\mathrm{Z}$ also seen to be less interested in interacting face to face. Instead, they love to do virtual interaction. They prefer to be in the room rather than to play outdoors. Thus, learning activities can help the students interact with them. This would train their communication skills while helping to improve self-esteem to speak in public.

The government has introduced many reforms in education. Among others, the use of Virtual Learning Environment (VLE) is widely used in the education system. According to Mohd Azli \& Abdul Latif (2012), the variety of methods and the use of technology in implementing learning activities can encourage students as active participant and is expected to increase the success of the goal Student learning. Mohd Azli, Wong \& Noraini (2016) in their study, stated that the learning process using the blended learning approach (including the use of Frog VLE platform) is an approach to 
address the needs of the diversity of students' learning style in producing positive impact to student skills.

In addition, social media usage can also be one of the ways of learning for a new generation. Social media tools such as YouTube, WhatsApp and Telegram can be a platform in delivering online lessons. According to the Renda Study (2017), students have positive perception about application of Youtube in class. In addition, they also stated that the application of Youtube has increased their learning interest. The use of video in teaching also supported by Yunina, Punadji \& Anang (2016) in their studies that expressed video archers in learning to have significant influence on their work, learning outcomes, and students learning. Educational video arching can also enhance the understanding of the participants in the historical subject. As a tool, technology will be able to improve the quality, accelerate and make the learning process more effective (Tarkus, 2018).

However, control over the present resources need to be perform as there are many of the bad elements are easily dispersed with unlimited internet access. Should a noble value be applied to students in advance before we use sophisticated rules. Hence, the objective of the curriculum development, which is to inculcate value in learning, will give a balanced generation in academic and personality.

\section{Conclusion}

Ecological learning for Generation $\mathrm{X}, \mathrm{Y}$ and $\mathrm{Z}$ There are many significant differences. These differences are seen many of the reference sources, teaching methods and learning methodologies applied. However, there are still similarities in terms of school functions and teachers in which students are still in school to claim their knowledge. To ensure the effectiveness of teaching to these different generations, educators need to consider the difference in the educational ecology for each generation. Facing future changes with different generations is a huge challenge for educators. Therefore, educators should learn new important skills for future generations.

\section{References}

[1] Azizi Yahaya (2010). Hubungan Gaya Pembelajaran Dengan Pencapaian Akademik Pelajar. Seminar Memperkasakan Sistem Pendidikan, 19-21

[2] Bronfenbrenner (1986). "Ecology of the Family As A Context for Human Development Research Perspectives", Developmental Psychology.

[3] Carbo, M dan H. Hodges (1998). Learning Styles Strategies Can Help Students at Risk. Teaching Exceptional Children 20, Vol 4:55-58
[4] Corey Seemiller \& Meghan Grace (2016). Generation Z goes to college. San Francisco, CA: JosseyBass

[5] Dunn, Rita, Jeffrey S. Beaudry, and Angela Klavas. Survey of research on learning styles. California Journal of Science Education 2.2 (2002): 75-98.

[6] Feller, David (1996) The role of databases in support of computational chemistry calculations. Journal of computational chemistry 17.13 ISSN: 1571-1586.

[7] Frank Romanelli (2009), Learning Styles: A Review of Theory, Application, and Best Practices. American Journal of Pharmaceutical Education. 73 (1) Article 9.

[8] Gordon Thomas (1974). Teacher effectiveness training: T.E.T. New York: Wyden

[9] Hira, N. A. (2007). You Raised Them, Now Manage Them. Human Resource Management International Digest, ISSN 1967-0734 Vol. 15 No.7 :38-47.

[10] Kathryn Tyler (2007). The tethered generation. HR Magazine, May 1 2007, 41-46.

[11] Purkey, W. W. (1970). Introduction to theories of the self: Self-concept and school achievement. Open Access Library Journal, Vol 3 No.11

[12] Shahaimi, Shahfiezul \& Khalid, Fariza. (2016). Pengintegrasian Blended Learning dalam Pembelajaran Persekitaran Maya Frog (VLEFROG). Pendidikan Abad ke-21: Peranan Teknologi Maklumat dan Komunikasi serta Cabarannya. p52-71

[13] Suganda, Tarkus. (2018). Pengelolaan Pembelajaran Generasi Z. Seminar Pembelajaran Bagi Generasi Z. DOI: $10.13140 /$ RG.2.2.23700.60800

[14] Yunina Resmi Prananta, Punaji Setyosari, Anang Santoso (2016). Pemanfaatan Video Pembelajaran Materi Sejarah Perkembangan Kapal Laut Untuk Anak Generasi Z. Seminar Nasional Mahasiswa Kerjasama Direktorat Jenderal Guru dan Tenaga Kependidikan Kemendidik Budaya. Vol 2:1-8. ISBN: 978-602-71836-0-5 